\title{
Mindfulness-Based Stress Reduction (MBSR) for Reducing Stress Among Informal Caregivers of Schizophrenia Outpatients
}

\author{
Utami Nurhafsari Putri ${ }^{\mathrm{a}}$ and Dini Rahma Bintari ${ }^{\mathrm{b}^{*}}$ \\ ${ }^{a}$ Faculty of Psychology, Universitas Indonesia, Depok, Indonesia $;{ }^{b}$ Department of Clinical \\ Psychology, Faculty of Psychology, Universitas Indonesia, Depok, Indonesia \\ *Corresponding Author: \\ Dini Rahma Bintari \\ Clinical Psychology Department \\ Faculty of Psychology, Universitas Indonesia \\ Jl. Lkr. Kampus Raya, Depok, Jawa Barat \\ Indonesia, 16424 \\ Tel.: +62 217270004 \\ Email address: dini.bintari@gmail.com
}




\title{
Mindfulness-Based Stress Reduction (MBSR) for reducing stress among informal caregivers of Schizophrenia outpatients
}

\begin{abstract}
Mindfulness-based stress reduction (MBSR) intervention is proven to reduce distress and improve the well-being of individuals, including caregivers. This study aims to assess the effectiveness of MBSR in reducing stress levels in informal caregivers of schizophrenia outpatients. The research method was a single-subject pretest-posttest design, which was applied to four participants individually. Four quantitative measures (Perceived Stress Scale-10, Subjective Units of Distress (SUD), Mindfulness Attention Awareness Scale (MAAS), and a test for knowledge of schizophrenia) and a qualitative interview were used to assess the effects of MBSR intervention. Quantitative posttest resulted in reduction of scores in three stress measures: PSS score decreased by $8,6 \%$, that of SUD decreased by $33,95 \%$, that of MAAS increased by $24,37 \%$, whereas the score of knowledge on schizophrenia increased by $48,54 \%$. Qualitative results from observation and interview method showed a decrease in stress levels and increase in mindfulness and knowledge of participants about their condition as an informal caregiver of schizophrenia. The participants felt calm and more relaxed in living their lives. They also presented more self-understanding, gratitude, reflective capabilities, empathy, and control over their anger.
\end{abstract}

Keywords: caregiver; Mindfulness-Based Stress Reduction; MBSR; schizophrenia; stress

\section{Introduction}

In management of schizophrenia patients, family plays an important role as an integral part of the schizophrenia treatment system. Informal schizophrenia caregivers face a different challenge compared with other caregivers. The research by Gupta, S., et al. (2015) stated that schizophrenia caregivers are more prone to encounter difficulties in sleeping, insomnia, pain, headache, heartburn, anxiety, lack of resources in nurturing, and depression (American Psychiatric Association, 2000; Qualls and Zarit, 2004; Kovacs and Fauri, 2003) compared with noncaregivers. Problems from environmental factors may arise from stigma (Irawati, 2002), discrimination, and lack of social support from the surrounding community due to the destructive nature of schizophrenia patients (Agiananda, et al., 2007; Chang, et al., In Rokhmani, CF, 2014). Addition of role as a caregiver in the family will serve as a source of stress psychologically and economically (Clark \& Schene, in Schene, Wijngaarden, \& Koeter, 1996). Role captivity can also occur; in this condition, family members feel confined to their role as caregivers. This sensation develops when someone feels obligated to do something and when a tension forms between duty and inclination.

One of the intervention methods for stress reduction is mindfulness-based stress reduction (MBSR), which was developed in 1979 by Jon Kabat-Zinn. Among the other intervention methods that aim to reduce stress, MBSR focuses more on self-knowing process that help individuals to find comfort in unbearable situations (especially for caregivers). MBSR teaches individuals how to maintain themselves well and live healthier and become more adaptive to their environment. Attention is primarily directed to develop someone's understanding of the body, mind, and the interaction of his/her body and mind, leading to the emergence of insights regarding their mental and physical conditions (Kabat Zinn, 1996). 
Some literature results (Gupta, et al, 2015; Damayanti, et al, 2010; Irawati, 2002; Rokhmani, C. F., 2014; Irmansyah, 2002; Hobbs, 1997; Duxbury, Higgins \& Schoroeder, 2009; Bryant, 2003; Agiananda, 2006; Shamsaei F., Cheraghi F., \& Bashirian, S., 2015; Nairne, 2003; Stahl, Bob, \& Goldstein, Elisha., 2010) indicate the high burden and the number of stressful conditions that cause psychological distress on informal schizophrenia caregivers. MBSR also exerts a positive effect when used to reduce distress and improve the well-being of individuals, including caregivers (Kabat-Zinn, 1996; Kabat-Zinn, 1990; Brown \& Ryan, 2003; Stahl, Bob, \& Goldstein, Elisha., 2010; Weare, 2014; Biegel, et al, 2009). This research aimed to study the effectiveness of MBSR intervention in reducing stress levels in informal caregivers of schizophrenia outpatients. The research design is a pretest-posttest single-case study.

An informal caregiver provides treatment without payment, is a nonprofessional, and usually a family member or a spouse of the patient (Barrow, 1996). The most influential and closest family member with the patient usually acts as the primary caregiver (Merrit, 2001).

Psychological theories are used to identify individual characteristics and intrapsychic drives that contribute to caregiver motivation (Batson, 1990 in Kietzman, Kathryn G., et al., 2013). Some factors motivate caregivers to perform their roles; such factors include emotional attachment or sense of moral duty (Cicirelli, 1993 in Kietzman, Kathryn G., et al., 2013) and care-receiver expectations or perceptions of rejection when not performing the role of caregiver (Lyonette \& Yardley 2003 in Kietzman, Kathryn G., et al., 2013).

The caregiver primarily assists and take care of patients with limitations and who cannot take care of themselves. The roles of caregiver include personal care (e.g., bath, walking, dressing, eating, sitting or sleeping position, and toileting), household activities (e.g., bedding, washing, meal preparation, and window wiping), shopping and transportation (e.g., arranging bills and expenses), providing emotional support (e.g., assistance in maintaining the patients' social relationships and validating their behavior or perception), and monitoring treatment for schizophrenia patients (Dupuis, Epp and Smale, 2004).

Informal caregivers experience high levels of stress because they often encounter stressful situations and conditions. Caregiver stresses are associated with financial problems, burnout, physical/emotional fatigue, pain, and role overload. If stress continues unabated, caregivers can feel overwhelmed, scared, angry, frustrated, hopeless, and helpless. Caregivers, especially women, also often experience changes in lifestyle and social activities. Caregivers often face role-balance conflicts, namely, their role as workers and other roles. Emotionally, the stress experienced by informal caregivers is higher, especially if no help originates from other informal caregivers (Timonen, in Kovacs and Fauri, 2003). These emotional burdens are also experienced by informal caregivers of schizophrenia patients.

In general, families with schizophrenia outpatients lack information about the disorder but take the responsibility to care for the patients (Bruhn \& Rebach, 2014). Inadequate knowledge and skills can contribute to disappointment, stress, and frustration (Dewi, Hellen C., 2016). A number of studies have shown that families who nurse people with severe mental illness suffer considerable pressures and burdens and often receive assistance from mental health professionals (Saunders, JC, 2003).

Families undergo physical, psychological, spiritual and economic changes during provision of optimal care for patients (Dewi, E.P., 2016). Based on the results of several Biegel studies, 
Milligan, Putnam et al. suggested the positive relationship between the burden of caring for family members who suffer from mental disorders and psychological stress on caregivers (in Hobbs, 1997).

From the explanation above, we can conclude the severe condition of informal schizophrenia caregivers. This condition can lead to psychological distress and may affect the quality of relationships and treatment of schizophrenia patients.

Jon Kabat-Zinn developed a technique called MBSR in 1979. MBSR is a systematic and definite approach based on intensive mindfulness practices to teach people how to take better care of themselves, live healthier, and be more adaptive to life.

According to Kabat-Zinn (1990), MBSR consists of three main techniques: awareness of breath in sitting position, body scanning while lying, and posture of hatha yoga. These three techniques are recommended in various techniques implemented in eight weeks, with mentors and written or recording instructions as guides. Breathing technique is the simplest. Thus, most sessions will start with breathing techniques. During the first few weeks, the practitioner is instructed to perform body scanning techniques for about $45 \mathrm{~min}$ and to sit for $10 \mathrm{~min}$ every day. As MBSR progresses, the time for body scanning is reduced, whereas the time for sitting is increased. Yoga posture is collaborated on the basis of meditation. After eight weeks, practitioners should possess be well aware of what is best for them and can form an MBSR program to meet their personal needs (Kabat-Zinn, 1990). MBSR consists of various techniques that are applied in everyday life; these techniques include mindful breathing, mindful body scan, mindful walking, mindful eating, and yoga exercise (Stahl, Bob \& Goldstein, Elisha, 2015).

\section{Methods}

\section{Participant}

The criteria for the participants in the research sample included individuals with schizophrenic family member (either primary caregiver, substitute, complementary, or conjoint) and who are aged 30-60 years old with minimum degree of senior high school. The participants also experienced stress or were potentially experiencing stress due to caregiving and were willing to follow therapy. Selection of participants was completed using nonprobability sampling. Sample selection technique was purposive sampling in accordance with the criteria of participants.

\section{Research Design}

The design used in this research was single-subject design, in which the researcher administered MBSR intervention to schizophrenia informal caregivers. This research used quantitative and qualitative data collection to obtain more information about the participants' experience during treatment. The hypothesis of the research is as follows: MBSR effectively reduces stress of caregivers of schizophrenia outpatients. The indicators used to measure included the Perceived Stress Scale (PSS)-10, Subjective Units of Distress (SUD) scale, and Mindfulness Attention Awareness Scale (MAAS) and Psycho-Educational Intervention Material tests.

\section{Measures}

Analysis was performed by comparing quantitative and qualitative data from pretest and posttest results. PSS-10 is a self-reporting scale that is easily administered and aims to determine the 
tendency of individuals to perceive stress as a result of stressful situations over the past month in their daily life (Cohen, Kamarck, \& Mermelstein, 1983). SUD is a rating scale popularized by Wolpe and Lazarus (in Davis, Eshelman, \& M'Kay., 2008). SUD is used to examine indications of distress levels caused by individual mental images based on the user's subjective judgment (Wolpe, 1969). SUD is a Likert-scale test with answers scored up to 11 points ranging from 0 to 10. These measurements have been shown to feature a high correlation with physiological indicators of stress (Thyer, et al., 1984; Wolpe, 1982; Shapiro, 2001). MAAS, which was used in this research, has been adapted into Indonesian by Victoria Sendy in 2010. The number of items used totaled 14, with a validity coefficient of $0.418-0.772$ and reliability of 0.894 . Psycho-Educational Intervention Material test was conducted by the researcher based on the material provided during intervention. This instrument was prepared in questionnaire form to measure the participants' understanding of the material provided by the researcher. Three main materials were included in this questionnaire; they comprise psychoeducation materials about schizophrenia (9 items), stresshered (6 items), and mindset ( 7 items), with a total item of 22 items.

Qualitative data were gathered with interview and observation. The participants were interviewed individually with an unstandardized nonstructured interview protocol. The questions focused on the participants' experiences as schizophrenia caregivers. For evaluation, the participants were also inquired about their satisfaction with the implemented program. During observation, researchers observed the dynamics between caregiver and schizophrenia outpatients to understand the condition of each participant and changes, although not verbally delivered by the participants, that occurred as effects of intervention. The contents of interview comprised questions about the participants' informal and formal activities, including changes that transpired during intervention. The activities were connected with thinking, feeling, and behavior, which all affect the psychological condition of participants.

\section{Procedure}

Before starting, the preparation stage involved the study of literature and initial interviews and observation. The researchers prepared four measurements: PSS-10 items, SUD, MAAS, and a measuring tool to assess retention of material intervention (cognitive). Participants who have met the criteria were asked to follow intervention procedures. After the agreement and informed consent phase, the researchers and participants determined the schedule of therapy.

MBSR intervention, which was given to reduce stress levels in schizophrenia caregivers, consisted of six sessions plus pre-sessions and one session involving follow-up. In the design of intervention, the researcher used the book A Mindfulness-Based Stress Reduction Workbook as reference, and its development was based on the MBSR initiator Jon Kabat-Zinn (Stahl, Bob \& Goldstein, Elisha., 2010). The researcher made several adjustments to fit the goals and materials of therapy and considered the conditions and characteristics of participants. In this study, implementation of MBSR intervention was conducted individually. This intervention was performed by considering that all participants were informal schizophrenia caregivers. The participants included housewives who spend more time at home to take care of schizophrenia outpatients and other family members in their house. Participants should also perform other tasks outside their role as caregiver schizophrenia. Thus, implementation of intervention was more suitable if performed individually. Individual implementation would be more adaptive and flexible with the time of participants.

All six meetings were held once a week, in which the gap between meetings totaled 5-7 days within 60-80 durations of execution. Each session was held about 60-180 min and coincided 
with cognitive pretest (such as knowledge on schizophrenia, stress, and patterns of thinking), mindfulness techniques (such as breathing, body awareness, eating, and walking), psychoeducation, feedback, posttest (combining cognitive test with interview and observation), and daily tasks for caregivers. Between the fifth and sixth sessions, the gap was set to two weeks to determine the effectivity of intervention.

In this research, evaluations were conducted at the end of group intervention programs. Researcher compared the assessment results to detect the changing levels of stress PSS-10 and SUD), mindfulness condition, and cognitive aspect (understanding the psychoeducation material). Measurements were conducted to determine the differences between posttest and pretest results in each instrument and to calculate the percentages of differences that were observed. Thus, we could observe whether changes transpired before and after the intervention. Reduction in PSS-10 and SUD scores implied reduction in stress level, whereas enhancement in MAAS scores indicated better mindfulness. Increase in understanding of psychoeducation material showed that participants possessed better knowledge on schizophrenia, stress, and thinking patterns.

The intervention program with MBSR approach, which was applied to reduce stress levels in schizophrenia caregivers, was held six times, including pre-sessions and follow-up sessions. All six meetings were held once a week, in which the gap between meetings totaled 5 to 7 days within 60-80 durations of execution. However, in between the fifth and sixth sessions, the gap was longer, which was about two weeks, to determine the effectivity of intervention.

In program execution, the modul could be modified depending on the conditions and progress of participants in each session. Thus, the order of material given, session, and duration of intervention can be possibly changed. Nevertheless, adjustment would not change the important points or main aspect from the already planned and previously modified MBSR model. To achieve the aim of each session, the researcher analyzed the results by comparing quantitative and qualitative data from pretests and posttests.

Table 1

MBSR Intervention Program for Informal Caregiver of Schizophrenia

\begin{tabular}{|c|c|c|}
\hline Session & Aim & Design Activities \\
\hline $\begin{array}{l}\text { Pre- } \\
\text { Session }\end{array}$ & $\begin{array}{l}\text { 1. Problems identification and stress condition } \\
\text { also experience as schizophrenia's informal } \\
\text { caregiver. } \\
\text { 2. Emotion's catharsis }\end{array}$ & $\begin{array}{ll}\text { 1. } & \text { Pre-test (instrument and early observation and interview) } \\
\text { 2. } & \text { Informed consent } \\
\text { 3. } & \text { Building relation/bonding process } \\
\text { 4. } & \text { Chatarsis } \\
\text { 5. } & \text { MBSR Technique: Mindful Check-in (3') + Breathing (5') } \\
\text { 6. } & \text { Informal Task } 1 \text { (Just Do It! Daily Basis) }\end{array}$ \\
\hline
\end{tabular}

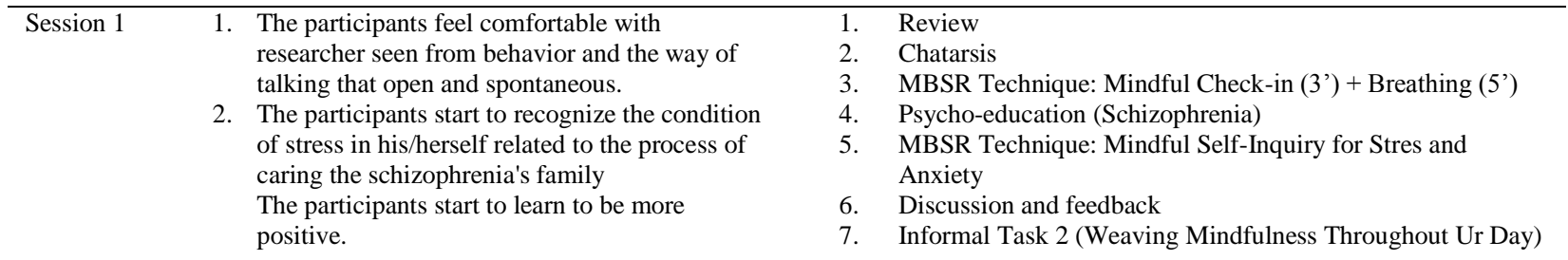


Table 1, cont.

MBSR Intervention Program for Informal Caregiver of Schizophrenia

\begin{tabular}{|c|c|c|}
\hline Session & Aim & Design Activities \\
\hline Session 2 & $\begin{array}{l}\text { 1. The participants have better understaning on } \\
\text { what is Schizophrenia and the condition of } \\
\text { stres. } \\
\text { 2. To adapt the participants focusing on practice } \\
\text { of mindfulness and giving space and time to } \\
\text { the to provide distance from things related to } \\
\text { schizophrenia. } \\
\text { 3. The participant capable to identify the negative } \\
\text { and the positive as Schizophrenia's caregiver. }\end{array}$ & $\begin{array}{ll}\text { 1. } & \text { Review + Chatarsis } \\
\text { 2. } & \text { MBSR Technique: Mindful Breathing (5') and/or Mindful } \\
& \text { Eating } \\
\text { 3. Psycho-education (Schizophrenia part II) } \\
\text { 4. Psycho-education (Stress) } \\
\text { 5. MBSR Technique: Mindful Self-Inquiry for Stres and } \\
\text { Anxiety } \\
\text { 6. Discussion and feedback } \\
\text { 7. Informal Task 2 (Weaving Mindfulness Throughout Ur } \\
\text { DayPart II + Eating Task) }\end{array}$ \\
\hline Session 3 & $\begin{array}{l}\text { 1. The partcipants feel more relaxed with thoughs } \\
\text { and feelings that arise } \\
\text { 2. The participants adapted to the mindfulness } \\
\text { practice } \\
\text { 3. The participants realize that body is a symbol } \\
\text { of happiness psychologically } \\
\text { 4. The participants arecapable to find insight } \\
\text { related to the pattern of relationship within } \\
\text { Schizophrenia's patients } \\
\text { 5. The participants find the advantages and } \\
\text { disadvantges that can affect his/herself or } \\
\text { others, including the patients (including the } \\
\text { good and bad impact }\end{array}$ & $\begin{array}{ll}\text { 1. } & \text { Review + Chatarsis } \\
\text { 2. } & \text { MBSR Technique: Mindful Check-in (3') + Breathing (5') } \\
\text { 3. } & \text { MBSR Technique: Loving-Kindness Meditation } \\
\text { 4. } & \text { Psycho-education (Inner Role \&Habitual Style of } \\
\text { Thinking) } & \text { Body’s Exploration: "is your body happy?" } \\
\text { 5. } & \begin{array}{l}\text { Discussion (about positive things as a schizophrenia } \\
\text { caregiver) }\end{array} \\
\text { 7. } & \text { Feedback + Probing insight } \\
\text { 8. } & \text { Informal Task 3 (Just Do it! Challenge ur Inner Rule) }\end{array}$ \\
\hline Session 4 & $\begin{array}{l}\text { 1. The participants are more experienced in } \\
\text { finding insight related to the pattern of his/her } \\
\text { relationship with Schizophrenia's patients and } \\
\text { able to be more positive (the negative emotions } \\
\text { far reduced when talking about the patients. } \\
\text { 2. The participants understand him/herself better, } \\
\text { including their advantages and disadvantages } \\
\text { that affect themself and their environment. } \\
\text { 3. The participants start to committed to always } \\
\text { practice the mindfulness technique that have } \\
\text { been learned through sessions }\end{array}$ & $\begin{array}{ll}\text { 1. } & \text { Review + Chatarsis } \\
\text { 2. } & \text { Probing insight } \\
\text { 3. } & \text { Repeat the MBSR Technique: (Mindful Check-in + } \\
\text { Breathing + Eating + Self-Inquiry + Loving-Kindness) } \\
\text { 4. } \\
\begin{array}{l}\text { Discussion (about positive things as a schizophrenia } \\
\text { caregiver) }\end{array} \\
\text { 5. } & \text { Feedback + Probing insight } \\
\text { 6. } & \text { Informal Task 4 (Just Do It! Reflect Others) }\end{array}$ \\
\hline $\begin{array}{l}\text { Follow-Up } \\
\text { Session } \\
\text { Closing and } \\
\text { termination }\end{array}$ & $\begin{array}{l}\text { 1. The participants to be more positive in the waf } \\
\text { of looking their condition as schizophrenia's } \\
\text { caregiver and more accepting about the patients } \\
\text { conditions } \\
\text { 2. The participants committed to always practice } \\
\text { the mindfulness technique that have been } \\
\text { learned through session, especially the } \\
\text { technique that give them the greatest impact. } \\
\text { 3. To know the progress of participants (including } \\
\text { cognition, emotion, behavior and condition of } \\
\text { body. } \\
\text { 4. To know the obstacle happened during } \\
\text { intervention pocess. }\end{array}$ & $\begin{array}{l}\text { 1. Review + Chatarsis } \\
\text { 2. Probing insight } \\
\text { 3. Discussion (different being then and now; feelings; and } \\
\text { hope) } \\
\text { 4. Ask commitment to choose \& practice: } \\
\text { a) Choose one of Formal MBSR Technique that will } \\
\text { always they practice everyday } \\
\text { b) Choose one of Informal (Daily Task) MBSR } \\
\text { Technique that will always they practice everyday } \\
\text { 5. Post-test (obstacle during intervention process, giving final } \\
\text { instrument, final interview and observation) } \\
\text { 6. Suggest: Informal Task 5 (The Gift of Rest) } \\
\text { 7. Termination }\end{array}$ \\
\hline
\end{tabular}

\section{Results}

Participants in this research included four women who are caregivers for their family members who are schizophrenia outpatients. Table 2 provides the detailed data of their demographics. The participants went through all the sessions of individual intervention of MBSR. 
Table 2

Participant's Background

\begin{tabular}{|c|c|c|c|c|}
\hline Participant's data & $\begin{array}{c}\mathrm{I} \\
\mathrm{PW}\end{array}$ & $\begin{array}{l}\text { II } \\
\text { Y }\end{array}$ & $\begin{array}{c}\text { III } \\
\text { E }\end{array}$ & $\begin{array}{l}\text { IV } \\
\text { R }\end{array}$ \\
\hline Gender & Woman & Woman & Woman & Woman \\
\hline Age & 52 & 41 & 46 & 35 \\
\hline Recent Formal Education & High School & D3 Nurse & High School & High School \\
\hline Marital Status & Married & Married & Married & Married \\
\hline Occupation & $\begin{array}{c}\text { Housewife - } \\
\text { Clinical Volunteers }\end{array}$ & Housewife & Housewife & Housewife \\
\hline $\begin{array}{l}\text { Economic Status } \\
\text { Relationship With Schizophrenia patients }\end{array}$ & $\begin{array}{c}\text { Middle - Average } \\
\text { Sister }\end{array}$ & $\begin{array}{c}\text { Below Average } \\
\text { Wife }\end{array}$ & $\begin{array}{c}\text { Below Average } \\
\text { Sister }\end{array}$ & $\begin{array}{l}\text { Middle-Average } \\
\text { Cousin }\end{array}$ \\
\hline
\end{tabular}

Based on Table 3, stress level decreased in all four participants. Quantitatively, this intervention succeeded in decreasing caregiver stress level measured through PSS-10, SUD, MAAS, and a test for measuring the understanding of intervention material. This result is accompanied by the increase in mindfulness practice and understanding of the conditions faced by the participants as schizophrenia caregivers. The following table summarizes the results of qualitative interventions on the four participants of this intervention.

Table 3

Analysis Results of Participant's Quantitative Scores

\begin{tabular}{|c|c|c|c|c|c|c|c|c|c|c|c|c|}
\hline \multirow[t]{2}{*}{$\begin{array}{l}\text { Participant } \\
\text { Initial }\end{array}$} & \multicolumn{2}{|c|}{ PSS-10 Score } & \multirow[t]{2}{*}{$\%$} & \multicolumn{2}{|c|}{ SUD Score } & \multirow[t]{2}{*}{$\%$} & \multicolumn{2}{|c|}{ MAAS Score } & \multirow[t]{2}{*}{$\%$} & \multicolumn{2}{|c|}{$\begin{array}{l}\text { Psycho- } \\
\text { education } \\
\text { Material Score }\end{array}$} & \multirow[t]{2}{*}{$\%$} \\
\hline & Pre & Post & & Pre & Post & & Pre & Post & & Pre & Post & \\
\hline PW & 9 & 11 & 18.18 & 6 & 4 & 33.33 & 39 & 74 & 47.3 & 46 & 62 & 25.8 \\
\hline $\mathrm{Y}$ & 34 & 32 & 5.88 & 8 & 7 & 12.5 & 37 & 44 & 15.9 & 22 & 48 & 54.17 \\
\hline $\mathrm{E}$ & 12 & 12 & 0 & 6 & 3 & 50 & 66 & 76 & 13.16 & 25 & 59 & 57.63 \\
\hline $\mathrm{R}$ & 19 & 17 & 10.53 & 5 & 3 & 40 & 56 & 71 & 21.13 & 23 & 55 & 58.18 \\
\hline
\end{tabular}

In qualitative analysis, some changes were observed by the researcher and reported by the participants. Three participants, PW, E, and R reported almost similar results: they felt more relaxed, comfortable, and calm after the intervention. At the end of the program, the participants can recognize and understand themselves especially about uncomfortable thoughts and feelings that make them feel overwhelmed. They can also empathize with the patients and accept responsibility as schizophrenia caregivers and family members (mother, brother, and others). The participants realized that the feeling of anger still appeared, but they can control themselves and showed more patience. They reported that the program helped them reduce their carelessness and focus more on activities. The participants practiced MBSR techniques every day and wanted to serve as example for others, provided information, and invited the people closest to them to participate in practicing MBSR techniques. A positive impact was felt by the closest persons to the participants (husbands of E and R; PW's husband followed her). E and R also invited other family members to participate in implementing MBSR technique, which they had learned, and also provided information on how to use the booklet provided by the researcher. Finally, the participants also reported to possess higher gratitude and reflective ability about life.

One participant, Y, reported slightly different results. Although she felt positive changes after the program, she still felt high levels of stress and experienced difficulty in becoming mindful. Y 
much easily became mindful on tactile techniques (mindful eating and activities, such as bathing, washing, and cooking). Although she was still not mindful, Y could be calmer if she applied instructions on techniques related to the movement (e.g., breathing while performing dhikr using a finger). This program taught her a technique that could easily calm and relax her. Y also felt increased gratitude and constantly remembered to touch her chest whenever she felt angry or upset. She reported that the mindful loving-kindness technique was memorable and made her felt more relieved, friendly, and as if she had no enemies. Y also claimed that she acquired knowledge that made her understand about her husband's illness and should share information with others.

\section{Discussion}

Quantitative measurements indicate a decrease in stress levels in all participants. This result is in accordance with the benefits of mindfulness, which brings clarity and awareness to all internal experiences that can play a strategic role in balancing the gas and brakes of sympathetic and parasympathetic nervous system, which involves a nerve that directly plays a role when an individual faces a stressful situation. With the existence of distance, the individual learns to be more aware that the implemented practice helps caregivers to accept both pleasant and unpleasant realities and to come up with solutions to overcome his/her dissatisfaction and make changes.

Viktor Frankl (in Stahl, Bob \& Goldstein, Elisha, 2010) states that a gap exists between stimulus and response. Spacing means that the individual observes what currently occurs, rather than directly reacting and dissolving with what transpires within themselves. Within that distance, we possess power to choose how to response. This sensation was also felt by the three participants, PW, E, and R. They claimed that now, they can better control their feelings of discomfort and become more relaxed in responding to problems. All three participants can provide distance and pause in responding to their discomfort. Changes in $\mathrm{R}$ and $\mathrm{E}$ were also felt by their closest relatives.

PW, E, and R reportedthe insight that everything occurs on its own time. Thus, they need not to be too pushy, rushed, and worried about things, especially about things that cannot be controlled nor changed. Results showed a change of perspective on the three participants when assessing stressful situations. The situation that was once considered stressful is no longer viewed as something that threaten and can cause stress in the three participants.

By contrast, changes in participant $\mathrm{Y}$ were the least compared to the other three participants. At the information level, improvement in MAAS scores in posttest results implies that Y should be more mindful. However, $\mathrm{Y}$ fails to reach the stage of practicing mindfulness in everyday life. This less significant change is influenced by the high stress level that has been prevailing for years. Thus, Y will require longer time to recover from stress.

Possibly, the personality aspect affected the results, especially in participant Y. Participant Y possesses the characteristic features of histrionic personality. Y's tendency for histrionic attitude is also an important factor. This condition significantly influences intervention using mindfulness techniques. Mindfulness presents the characteristics of awareness and attention, characterizing the core of mindfulness (Deikman, 1982; Martin, 1997; in Brown \& Ryan, 2003). Y is more self- 
focused and presents difficulty of empathizing with others; empathy is one of the important aspects that must be achieved in MBSR interventions (Stahl, Bob \& Goldstein, Elisha., 2010). Such assumption was arrived at given that a histrionic individual focuses on himself and is intolerant of delaying the fulfillment of his desires (Choca, James, 1980; Millon, T., \& Davis, R. D., 1996). Implementation of individual intervention is less suitable for individuals with histrionic personalities such as Y. Y cannot fulfill her needs during the intervention.

Individuals with histrionic personality prefer activities that allow them to present themselves in front of other people. They usually attempt to stand out to gain praise and attention without others knowing their initial intention (Choca, James, 1980; Millon, T., dan Davis, R. D.,1996). The implemented individual intervention proves unsuitable for individuals with histrionic personality, such as Y. Y could not fulfill his/her needs during the intervention. This result was also confirmed by Y, who said that she would be remarkably happy if other people underwent the intervention with her. This particular reason caused $\mathrm{Y}$ boredom and become less enthusiastic throughout the intervention. During the intervention, $Y$ experienced difficulties in understanding instructions and discussions.

Participant $\mathrm{Y}$ showed lack of focus and nodded more for formality, because she did not understand what the conversations were about. She only understood if the topic was delivered in detail and with practical applications. Y would much easily understand concrete-operational information than conceptual (abstract) information. This situation would serve as barrier in this intervention, because MBSR intervention requires thorough understanding of language. This result is also possibly connected with inadequate family and environment conditions. The low social-economic environment will affect the way of thinking and usage of daily language.

Nevertheless, the provision of MBSR intervention is still proven to exert an effect on the reduction of stress level in Y. Such effect can be observed from Y's quantitative results, which showed a decrease in her stress level and increase in her mindfulness and information. However, this increase is not as high as those of the other three participants. Qualitatively, Y alone noticed the benefits of following this intervention. She felt better and observed that breathing techniques combined with dhikr using fingers more easily calms her down. Y also remembered well and was much interested with mindful eating technique. She could focus on her food and forget the things that cause her discomfort. $\mathrm{Y}$ also felt very grateful for having undergone a mindful lovingkindness technique that taught her about gratitude, especially for her beating heart. If Y felt resentful and hateful, she immediately touched her chest and sensed that she needed not to spread such hatred. All these techniques are appealing and not boring to Y. We can conclude that people with histrionic personalities, such as Y, are more suited to be given motion-related MBSR techniques (tactile).

The presence of a professional who can hear the caregivers out and understand them provides them happiness and a sense of comfort (Yalom, dalam Kurtz, 1997). This thought was disclosed by all participants as an impression that they felt throughout the intervention. The participants felt that they had friends to talk and knew other people who were open to discussion, giving them relief because they could lament with guaranteed secrecy. Overall, the participants felt that they were not alone anymore. The day when they met the researcher became the day they were waiting for. 
We can conclude that MBSR is an intervention that can be considered means for handling stress of schizophrenia caregivers. In general, the participants exhibited increasing positivity as a result of intervention. The success of intervention could be affected by easy understanding and usage of materials and implementation and adjustment during intervention to match their conditions and needs creatively. These steps must be accomplished to prevent participants from facing difficulties, to motivate them to continue their activities, and to allow them to recognize the advantages of this intervention. The capability of the intervention to adapt and synergize to the aspects that are already present in the participants themselves (such as religious and cultural aspect) eased the acceptance of the intervention and touched the heart of participants. The attitudes of the researcher also determined the success of sessions, in which rapport is the most important thing to be noticed. A genuine attitude also served as a factor in determining the conducive relationship between client and therapists. The same gender of the researcher and participants also aided in the success of this intervention.

In general, after MBSR intervention, decreases were observed in scores on PSS-10 and SUD scales, whereas increases were noted in scores on MAAS and Psycho-Educational Intervention Material tests. Results showed that MBSR effectively reduces stress in caregivers of schizophrenia outpatients. MBSR interventions exerted positive effects on all participants. Thus, MBSR is an effective psychological intervention for stress reduction in schizophrenia caregivers. In general, participants experienced positive improvements as a result of the intervention. All participants felt helpful and easily performed mindful breathing techniques. However, each participant featured uniqueness and preference for different techniques, including mindful eating, loving-kindness, and body awareness techniques.

\section{References}

Agiananda, F. (2006). Pengkajian beban kebutuhan dan sumber daya keluarga dalam merawat penderita skizofrenia: sebuah studi kasus. Tesis PPDS Departemen Psikiatri. Jakarta: Fakultas Kedokteran Universitas Indonesia.

American Psychiatric Association. (2000). Website: http://www.apa.org/news/press/releases/stress/2011/health-risk.aspx. Accessed on September 9, 2016

Barrow, G.M. (1996). Aging, the individual, and society (6 ${ }^{\text {th }}$ ed.). Amerika: West Publishing Company.

Biegel, et al,. (2009). Mindfulness-Based Stress Reduction for The Treatment of Adolescent Psychiatric Outpatients: A Randomized Clinical Trial. Journal of Consulting and Clinical Psychology, 77, 855-866.

Brown, K. W., \& Ryan, R. M. (2003). The Benefits of Being Present: Mindfulness and Its Role in Psychological Well-Being. Journal of Personality and Social Psychology, 84, 822-848.

Bryant, (2003). Handbook of Death and Dying. California: Sage Publications, Inc.

Choca, James. (1980). Manual for clinical psychology practicums. Bruner Mazel, New York.

Cohen, S., Kamarck, T., \& Mermelstein, R. (1983). A global measure of perceived stress. Journal of Health and Social Behavior, 24, 385-396.

Damayanti, R. \&Hernawaty, T. (2010). Pengaruh terapi suportif keluarga terhadap kemampuan keluarga merawat klien gangguan jiwa di kecamatan Bogor Timur. Indonesia.

Davis, M., Eshelman, E. R., M'Kay, M. (2008). The Relaxation \& Stress Reduction Workbook (6th ed). Oakland: New Harbinger Publications, Inc.

Dewi, E.P. (2016). Pengalaman keluarga dalam merawat pasien skizofrenia takterorganisir di rumah sakit jiwa daerah Surakarta. Skripsi. Surakarta: Universitas Muhammadiyah Surakarta.

Dewi, Hellen C. (2016). Support group untuk caregiver penderita skizofrenia. Tesis. Depok: Universitas Indonesia.

Dupuis, S., Epp, T., \&Smale, B. (2004). Caregivers of persons with dementia: roles, experiences, supports, and coping. Waterloo: University of Waterloo.

Duxbury, L., Higgins, C., \& Schroeder, B. (2009). Balancing Paid Work and Caregiving Responsibilities: A Closer Look at Family Caregivers in Canada. Canada 
Gupta, S., dkk. (2015). Assessing health status in informal schizophrenia caregivers compared withhealth status in non-caregivers and caregivers of other conditions. BMC Psychiatry.DOI 10.1186/s12888-015-0547-1.

Hobbs, T. T. (1997). Depression in the caregiving mothers of adult schizophrenics: a test of the resource deterioration model. Community Mental Health Journal. $\quad$ Vol. http://proquest.umi.com/pqdweb?index=0\&did=960647661\&SrchMode=1\&sid=2\&Fmt=4\&VInst=PROD\&VType=PQ D\&RQT $=309 \&$ VName=PQD\&TS=1228099903\&clientId=63458. Accessed on October 16, 2016

Irawati, I. (2002). Peran serta keluarga dalam reintegrasi pasien skizofrenia kemasyarakat. Mitra Skizofrenia, 21-23.

Irmansyah. (2002). Keluarga Penderita Skizofrenia bias Berperan Besar. Mitra Skizofrenia, 4-5

Kabat-Zinn, J. (1990). Full catastrophe living: Using the wisdom of your body and mind to facestress, pain, and illness. New York: Dell.

Kabat-Zinn, J. (1996). Mindfulness meditation: What it is, what it isn't and it's role in health care and medicine. In Y. Haruki \& M. Suzuki (Eds.), Comparative and psychological study on meditation (pp. 161-170). Delft, Netherlands: Eburon Publishers.

Kerlinger, F. N. \& Lee, H. B. (2000). Foundation of behavioral research(4 ${ }^{\text {th }}$ Ed). Harcourt College Publ.

Kietzman, Kathryn G., Benjamin, A.E., \& Matthias, Ruth E. (2013). Whose choice? Self determination and the motivations of paid family and friend caregivers. Journal of Comparative Family Studies. Vol. 44(5). 519-540.

Kovacs, P.J., \&Fauri, D.P (2003). Handbook of death and dying.Volume 1: The Presence of Death. Thousand Oaks, CA: Sage Reference.

Merrit, R. P. (2010). The decision making process of informal caregivers of dementian family members regarding nursing home placement. Richmond, Virginia: Virginia Commonwealth University.

Millon, T., dan Davis, R. D. (1996). Disorders of personality: DSM IV and beyond (2 ${ }^{\text {nd }}$ ed). Wiley Inc.

Nairne, J. S. (2003). Psychology The Adaptive Mind (3rd ed). Amerika Serikat: Thomson Wadsworth.

Qualls, S., \&Zarit, S. (2004). Aging family and caregiving. New Jersey: John Wiley \& Sons, Inc.

Rokhmani, C.F. (2014). Intervensi logoterapi untuk meningkatkan strategi koping istri sebagai caregiver pasien skizofrenia sebuah studi kualitatif di poliklinik psikiatri rsud dr. moewardi surakarta. Masters Thesis, Universitas Sebelas Maret.

Saunders, J. C. (2003). Families living with severe mental illness: a literature review. Mental Health Nursing. 24. 175-198. Doi: $10.1080 / 01612840390160711$

Schene, A.H., Wijngarden, B. V., \&Koeter, M.W.J. (1996). Family caregiving in schizophrenia: domains and distress. Schizophrenia Bulletin. [On-line] http://schizophreniabulletin.oxfordjournals.org/content/24/4/609.full.pdf+html. Accessed on October 18, 2016

Shapiro, F. (2001). Eye movement desensitization and reprocessing:Basic principles, protocols, and procedures( $2^{\text {nd }}$ ed.).New York, NY: Guilford Press.

Shamsaei F., Cheraghi F., \&Bashirian, S., (2015). Burden on Family Caregivers Caring for Patients with Schizophrenia. Iran Journal Psychiatry. 10(4). 239-245.

Stahl, Bob \& Goldstein, Elisha., (2010). A mindfulness-based stress reduction workbook. AmerikaSerikat: New Hurbinger Publications, Inc.

Thyer, B.A., Papsdorf, J.D., Davis, R., \& Vallecorsa, S. (1984). Autonomic correlates of the subjective anxiety scale. Journal of Behavior Therapy and Experimental Psychiactry, 15, 3-7.

Weare, K. (2014). Evidence for mindfulness impacts on the well-being and performance of school staff. Website: https://mindfulnessinschools.org/wp-content/uploads/2014/10/Evidence-for-Mindfulness-Impact-on-school-staff.pdf. Accessed on October 16, 2016.

Wolpe, J. (1969). The practice of behavior therapy. New York: Pergamon Press. 